\title{
The Level of E-Learning Integration at the University of Jordan: Challenges and Opportunities
}

\author{
Muhannad Al-Shboul ${ }^{1}$ \\ ${ }^{1}$ Department of Curriculum and Instruction, Faculty of Educational Sciences, The University of Jordan, Jordan \\ Correspondence: Muhannad Al-Shboul, Assistant Professor of e-Learning, Department of Curriculum and \\ Instruction, Faculty of Educational Sciences, The University of Jordan, P. O. Box 13244, Amman 11942, Jordan. \\ E-mail:malshboul@ju.edu.jo
}

$\begin{array}{lc}\text { Received: March 4, } 2013 & \text { Accepted: March 11, } 2013 \quad \text { Online Published: March 12, } 2013 \\ \text { doi:10.5539/ies.v6n4p93 } & \text { URL: http://dx.doi.org/10.5539/ies.v6n4p93 }\end{array}$

This research study was funded by the Deanship of Academic Research at the University of Jordan.

\begin{abstract}
E-Learning is playing a significant role in education to improve students' skills and teach them new ways for managing their knowledge and information. Many universities and institutions of higher education have recognized the value of the Internet in changing the way people learn. Traditional classroom courses can be augmented with interactive materials on the Web and old fashioned courses can be transformed into e-Learning environments. However, few academic institutions have been able to embrace e-Learning in a way that enables widespread innovative uses of educational technology throughout the institution. Despite the fact that there are some cases of Faculty in Jordanian Universities carrying their own experiments and using trial and error to search for innovations to enhance their courses, these efforts are not matched with a large-scale institutional support and structure to move these initiatives from innovations to standards. We need to spread the culture of using e-Learning technology to enhance the quality of learning. Thus, this study aims to investigate the degree of e-Learning integration at the University of Jordan. Specifically, the purpose of this study was to identify potential factors related to the use of e-Learning tools by faculty members (users and non-users) at this University. This study was conducted during the Fall Semester of 2012/2013 with a population consisted of 1314 faculty members. Overall, the results of this study revealed that an increase in salary, teaching workload, and training are the most important factors related to faculty use of e-Learning tools at this Jordanian university. Furthermore, the results showed that faculty rank and perceived use of e-Learning tools were related to the level of faculty use of e-Learning.
\end{abstract}

Keywords: e-Learning, information technology, educational technology, higher education, Jordan

\section{Introduction}

The increased involvement of technology in all aspects of our lives places educational institutions under pressure to include these aspects at the heart of their learning. Undoubtedly, the implementation of e-Learning systems in higher education has enabled a dramatic change in teaching and learning practices. The success of e-Learning adoption across an organization depends on several factors, for example, the availability of technology, how instructors are supported in its use, and the integration of technology within the faculty member teaching experience (Al-Adwan \& Smedley, 2012). E-Learning enables instructors to model and present many different kinds of information in dynamic ways that help students learn more rapidly and effectively by doing rather than observing. E-Learning is an important tool for delivery, interaction, and facilitation of both teaching and learning processes (Jamlan, 2004).

Accordingly, there is no doubt that e-Learning has the potential to play a major role in the continued development of higher education teaching and learning. However, academic institutions wanting to embrace a successful e-Learning strategy must ensure they are fully prepared both culturally and technologically. If they fail to put the necessary foundations in place - instilling an institution ethos promoting e-Learning across all levels of an institution, developing a robust technical infrastructure, and providing technology support for faculty members - the opportunities offered by e-Learning will be missed (Macpherson, Homan, \& Wilkinson, 2005). 
One of the main advantages of an e-Learning is that faculty member can design asynchronous course activities and communication outside the face-to-face class (Al-Shboul, 2011). However, "effective use of [e-Learning] tools does not result from the use of the tools but rather from the integration of the tools in teaching" (Nelson, 2003 , p. 3). If we are to understand and realize the potential of e-Learning tools in higher education from a learning perspective, we must understand the perceptions of both faculty users and non-users of the e-Learning tools in terms of the factors that may affect (positively or negatively) their use of such technology. Therefore, more research is needed to examine the factors related to faculty members (users and non-users) at higher education institutions in their decision of whether or not to use e-Learning tools in their teaching practices, in addition to explore e-Learning integration level in an educational settings (Anderson, 2003; Hannafin, 1999; Kagima, 2001; Morgan, 2003; Muilenburg \& Berge, 2001).

Faculty members at the University of Jordan (UJ) are being encouraged to become involved in e-Learning activities. Hence, the purpose of this research paper was to examine the utilization level of e-Learning integration at the University of Jordan. In particular, the study at the UJ determined factors that influenced the involvement of full-time faculty members in e-Learning programs within the Jordanian Higher Education system.

Moreover, the Utilization Domain of Instructional Technology, adapted from Seels and Richey (1994), focuses on the use of specific instructional technology through innovation, implementation, and institutionalization to encourage and support its applicable use in educational settings. E-Learning tools lie within this domain. This study examined the level of e-Learning integration at one of Jordanian higher education institutions as well as investigated those factors that faculty members identify as being influential in their decision and ability to use e-Learning tools in instruction.

Consequently, to assess the level of e-Learning integration at the UJ, to examine the degree of implementation of e-Learning by the faculty members, and to determine the factors that could influence the involvement of faculty members in e-Learning, a paper-based survey was developed and sent to the population of the study which consisted of 1314 faculty members of the UJ to determine potential factors that may have a positive or negative effect on the level of faculty use of e-Learning along with the integration level of e-Learning in instruction at this university. Data was collected, during the Fall Semester 2012/2013, and analyzed by using descriptive statistics. Results indicate that faculty generally perceive e-Learning as a positive force in helping students' achieve their learning objectives. Furthermore, the results of the study reveal that faculty members training, well prepared online courses and learning materials, sufficient groundwork for the smooth transition from traditional modes of learning towards e-Learning delivery, and the implementation of a more robust technological infrastructure to support all the technical aspects are necessary to launch, support, and sustain e-Learning.

The expected audiences for this research study are faculty at higher education institutions, university administrators, and faculty development directors. The results of this study will benefit the expected audience by identifying what is currently taking place with e-Learning integration at one higher education institution in Jordan. This study also identified factors that differentiated faculty users versus non-users of e-Learning tools. This information may assist faculty at higher education institutions in Jordan to have successful implementation of e-Learning in their classrooms.

This study is organized as follows: Section (2) provides a literature review of faculty perceptions about the use of e-Learning in instruction and the major factors affecting faculty use of e-Learning technology. Section (3) introduces the problem of the study, describes the purpose of the study, and lists research questions. Section (4) describes the research method that was used in the study, including a description of the subjects, research design, and data analysis. Section (5) presents the results and findings of the study, Section (6) provides a discussion related to the level of e-Learning integration at $\mathrm{UJ}$ and its relation to some factors, and Section (7) provides conclusion and recommendations.

\section{Literature Review}

E-Learning systems allow faculty members to manage their courses electronically and to use technology tools in teaching. E-Learning is a fairly new suite of software tools that have been used in an educational setting for less than a decade. Moreover, e-Learning enables instructors to extend the classroom beyond its traditional boundaries of time and space (Warner, 2003). It is important to review relevant literature to the integration of such technology in higher education to guide research questions and establish investigations of importance.

While some faculty members have adopted technology enthusiastically, others have been much slower to integrate new technology into their teaching. There are some faculty members who appear reluctant to accept technology integration or use these tools in their teaching (Cuban, 2001; Morgan, 2003; Walsh, 1993). 
Organizational cultures and norms within higher education institutions also influence the adoption and deployment of technology (Cho \& Berge, 2002).

Most of the literature found that the need for faculty development and institutional support (encouragement and incentive) are consistently identified as primary factors influencing the use of new instructional technology in higher education settings (Al-Shboul, 2010; Butler \& Sellbom, 2002; Morgan, 2003; Ndahi, 1999).

Current research indicates that many faculty members choose to integrate e-Learning tools for a variety of reasons. Some are interested in the convenience factor the tools provide for communication with students, while others are motivated because of administrative pressure (Al-Shboul, 2007; Macpherson, Homan, \& Wilkinson, 2005; Reilly, Vandenhouten, Gallagher-Lepak, \& Ralston-Berg, 2012). Whatever the reasons, most e-Learning tools are currently underexploited in teaching (Nelson, 2003). Many university faculty members are using e-Learning tools to supplement their traditional classroom instruction (Nelson, 2003; Warner, 2003). Clifford, Earp, and Reisinger (2003) indicated that data published in Market Data Retrieval's 2002-2003 Annual Survey of Instructional Technology Trends in Higher Education show that 91 percent of colleges and universities reported using some type of e-Learning tools in 2002. Most of the reviewed research indicated that the primary use of e-Learning tools is mainly for communication and convenience purposes (Chin, 2004; Coogan, 2009; Dietz-Uhler \& Bishop-Clark, 2001; Grandgenett, 2001; Nelson, 2003; Selim, 2007; Strudler \& Wetzel, 1999).

Gautreau (2011) found that 100 percent of faculty surveyed used Learning Management Systems (LMS) communication tools in their daily-life activities, but only about one-third of the same faculty used these tools in their teaching. Thus, "some faculty members are simply unable to connect technology use to [their] teaching" (Nelson, 2003, p. 21). The increasing availability of effective technology justifies investigating the level of faculty involvement and the challenges that are associated with using these technologies. Some of these technologies are new to many institutions and faculty (Ndahi). Additionally, when people within an organization plan for using new or existing technology, there are several barriers to their efforts that they are likely to encounter. A consideration of the barriers faced by organizations may help organizational leaders find solutions to reduce or minimize these obstacles (Cho \& Berge, 2002).

Ely (2002) indicated that traditional approaches to teaching and learning in postsecondary environments continue to be a dominant force for a number of reasons: (a) professors hesitate to change; (b) some faculty do not have the skills to use information technology and are not especially eager to learn; and (c) there is an institutional reluctance to provide sufficient personnel and financial assistance to facilitate the use of networking.

Nelson (2003) indicated that the integration of technology in teaching in higher education has become an important issue; according to him, "[t]echnology is continuing to be a driving force in the delivery of education. Most college and university campuses have and continue to designate resources to technology integration. For faculty members, this is exciting and challenging" (p. 32). Ely (2002) indicated that technology integration in instruction is one of the current trends in educational technology; he stated that "[f]aculty members at institutions of higher education have usually been late adopters of innovations for teaching and learning" (p. 11). Therefore, the increasing availability of technology in instruction justifies investigating the level of faculty involvement and the challenges that are associated with using these technologies (Ndahi, 1999).

Green (2002) indicated that e-Learning tools have become an important component of the institutional instructional infrastructure: both the percentage of classes that use e-Learning resources and the number of institutions that have established a campus standard for a e-Learning product are on the rise. As more instruction includes the use of these tools, issues in effective technology use become more important (Nelson, 2003). Investigating the level of faculty involvement and the challenges that are associated with using e-Learning systems have become essential issues in higher education. However, a review of the literature reveals that, while several studies focus on the features and functionality of different e-Learning systems, very few studies address or focus on the perceptions of e-Learning faculty users and non-users in terms of factors affecting their use of e-Learning tools, that is, motivating and/or inhibiting factors related to faculty use of e-Learning tools.

Furthermore, according to Feeney (2001), "[t] $]$ he gap between technology adoption and technology use in teaching has been noted worldwide" (p. 11). Therefore, "understanding the rate of adoption in any given situation requires analyzing factors that may facilitate the adoption and those that may operate as barriers to adoption" (Butler \& Sellbom, 2002, p. 22). Ndahi (1999) indicated that the reasons faculty members are uncomfortable or resistant to using interactive computer-based instruction, such as e-Learning tools, at higher education institutions are not made clear. Morgan (2003) found that some faculty members are reluctant to adopt e-Learning technology. Chapman and Mahlk (2004) pointed out that providing the latest technology to learners does not ensure improved learners' participation or achievement; also, technology does not necessarily improve 
instruction. Hence, attitudes toward technology were found to be an important element in the successful integration of technology (Christensen, 2002).

Molenda and Sullivan (2003) indicated that many colleges and universities are coming to understand that their technology investments are unlikely to have an impact on improved teaching and learning until they actively support faculty use. Crawford and Rudy (2003) stated that "[t]he future of technological successes at higher education institutions depends not only on the availability of technology, but also on the extent to which faculty are supported as they develop innovative ways to integrate technology into the learning experience" (p. 23).

Rogers (2000) examined barriers to technology adoption; she found that barriers to successful technology adoption in education appear to have internal and external sources. Internal barriers may be summarized as "teacher attitude" or "perceptions" about a technology, in addition to a person's actual competency level with any technology. External sources include the availability and accessibility of hardware and software, the presence of technical personnel and institutional support, and an appropriate and adequate program for staff development and skill building. Barriers that cross internal and external sources are lack of time and funding and the unique culture of the institution. Furthermore, Rogers found that "attitudes and perceptions of key individuals in the academic institutions may become the major barrier to adopting any technology" (p. 467).

Wilson (2003) found that the three most common barriers to successful use of technology in higher education were identified as time, funding, and faculty reward systems. Having enough time is the most critical element to successfully implementing technology. New technologies are expensive, both to purchase and to support, and no technology implementation project can succeed without adequate infrastructure funding. For this reason, Wilson suggested that programs need to be developed to help faculty learn new technology.

Chism (2004) found that just-in-time training and incentives and rewards are required when dealing with supporting faculty use of instructional technology. She also found that organizational development is important for the success of faculty development; she states, "[p]romoting faculty change in the use of information technology goes hand-in-hand with organizational development. Efforts taken to foster a climate of experimentation focus on leadership, rewards, policies and procedures, and resources" (p. 44).

The findings of Ndahi's (1999), Muilenburg and Berge's (2001), Butler and Sellbom's (2002), Anderson's (2003), and Morgan's (2003) studies showed that institutional support and encouragement and faculty training are essential factors for successful implementation of new technology in higher education teaching and learning environments. Also, these studies indicated that to successfully implement new technology in teaching and learning, educational institutions must address these barriers to faculty adoption. They also emphasized the need for further research to investigate faculty perceptions of e-Learning, to validate their findings, to analyze the utilization of e-Learning in higher education, and to determine factors influencing faculty use of e-Learning Web-based tools and perceived factors to not use e-Learning Web-based tools.

Most of the reviewed literature identified several factors that are related to the use of e-Learning tools; that is, factors that faculty members believe are important either in facilitating the use or in creating barriers that work against the use of such technology. The most common factors that prevent faculty members from using e-Learning tools in their teaching are a lack of time to learn new technology (workload); the lack of adequate training in the use of technology; and, most importantly, a perceived lack of institutional encouragement, support, and incentives.

Accordingly, identifying the factors that contribute to faculty willingness or unwillingness to use e-Learning is important. They will provide an understanding for why faculty do or do not utilize e-Learning in their instruction. Understanding what truly motivates faculty to employ e-Learning could help administrators in encouraging faculty who have stronger intrinsic motives over personal needs. Examining barriers to e-Learning could help administrators reduce or minimize those obstacles.

In short, past researchers studying the diffusion of distance education technology and e-Learning have focused on the attitudes of faculty who have used it. As a result, attitudes and perceptions of potential users toward such technology are neglected, and a need exists to understand faculty attitudes toward distance education technology such as e-Learning, particularly attitudes of the majority of faculty, those who have not used distance education technology and e-Learning (Reiser \& Dempsey, 2002). Babić (2012) indicated that there is a need for better representations of why some faculty members adopt technology and why some faculty members resist it.

Despite the fact much of the literature in higher education discussed the importance of the faculty members, this group has been largely neglected by the research. Research on faculty is lacking in quality and quantity, and little formal effort has been made to support faculty who tried to implement new technology, such as e-Learning. 
There is little information about the faculty who use e-Learning tools and research on faculty who have not used e-Learning tools is limited, and little research on faculty attitudes toward e-Learning has been reported (Al-Shboul-2011). Yet little is known about university faculty attitudes toward e-Learning in Jordan and its level of integration. Additionally, little studies conducted on faculty members' perceptions regarding factors related to e-Learning utilization.

In conclusion, most of the reviewed literature consistently emphasized the need for (a) identifying prevalent faculty attitudes toward e-Learning use; (b) comparing the identified attitudes and perceptions of e-Learning faculty users versus non-users; (c) determining the source of information on which these attitudes are based; and (d) comparing the reasons for differences between faculty with favorable attitudes toward e-Learning and faculty with unfavorable attitudes toward e-Learning. However, these four areas had the least amount of prior research available. In summary, the reviewed literature identified that the problems facing higher education faculty in integrating technology into their classes need to be addressed to improve the level of technology utilization. Thus, this study investigated the level of e-Learning integration at the UJ and examined factors that may affect faculty's attitudes toward the utilization of e-Learning into their teaching.

\section{Statement the Problem, Importance of the Study, and Questions of the Study}

The University of Jordan is the leading institution of higher education in Jordan established in 1962. The UJ took e-Learning and Information and Communication Technology-led development initiative in its vision since 2003, When the LMS was integrated into its information system; Blackboard in 2005 and Moodle in 2012. Thus, the increasing availability of effective technology and e-Learning tools at the UJ justifies investigating the level of faculty involvement and the challenges that are associated with using these technologies.

According to Feeney (2001), e-Learning has been the focus of recent scholarly attention. As integrating technology into higher education becomes an institutional imperative at universities all over the world, adoption of digital courses in a new e-Learning becomes both an organizational goal and a source of data upon which to evaluate performance. Furthermore, Feeney stated that higher education institutions face persistent challenges in the use of technology, with the e-Learning being the latest technology challenge. However, research indicated that one of the problems hindering the use of e-Learning and its related technology in higher education is faculty resistance (Kim, 2008).

Despite the expansion of distance education programs and its related technology, many faculties are reluctant to participate in distance education or use its related technology such as e-Learning (Oravec, 2003). Faculty reluctance has been linked to internal issues such as a lack of incentives and rewards systems to encourage faculty participation and a lack of an institutional framework to train distance teaching faculty (Irani \& Telg, 2007). Kim (2008) stated that one of the primary factors that influences faculty participation in distance education and its related technology is the effect on faculty workload.

In summary, the reviewed literature identified that the level of e-Learning use has increased as faculty perspectives toward such technology have been addressed (Ong, Lai, \& Wang, 2004; Roca, Chiu, \& Martínez, 2006). Therefore, the stated aim of this study is to assess the level of e-Learning integration at the UJ as well as to investigate and address those factors that faculty members identify as being influential in their decision and ability to use e-Learning in instruction.

\subsection{Statement of the Problem}

Technology by itself cannot be effective. Providing the latest technology to learners does not necessarily ensure improved learners' participation or achievement. Additionally, technology does not necessarily improve instruction. Faculty attitude toward technology was found to be an important element in a successful integration of technology (Afshari, Bakar, Luan, Samah, \& Fooi, 2009; Nelson). It is important to investigate the faculty's attitudes toward the utilization of e-Learning in their classrooms and their involvement in such technology. Consequently, this research study was conducted to investigate the level of e-Learning integration at the University of Jordan and to address the challenges that may affect e-Learning deployment at the indicated University.

A review of literature shows that many articles have been written comparing the functionality of different e-Learning tools; however, the level of e-Learning integration and the perceptions of e-Learning faculty users and non-users have rarely been addressed. Some scholars, such as Butler and Sellbom (2002), Morgan (2003), Muilenburg and Berge (2001), and Ndahi (1999), highlight a need to explore such issues.

In a recent study of technology innovations, Lynch (2002) found that, while 80 percent of colleges in his study have learning content management systems available, faculty only use these tools in 20 percent of courses 
offered. Why is such a low percentage of faculty members making use of e-Learning tools in educational settings? "Despite its potential benefits, the effectiveness of computer mediated communication when used to support learning in higher education is very variable, making it important to identify those factors which best predict successful implementations" (Tolmie \& Boyle, 2000, p. 138). However, research indicates that one of the problems hindering the use of distance education tools (technology) in higher education is faculty resistance (Kim, 2008). Research is needed to explore the faculty perceptions about the use of e-Learning tools in instruction in higher education institutions and to define the most important factors affecting e-Learning integration in education.

\subsection{Rationale for the Study}

Some of the reasons for conducting this study are the lack of studies conducted on this area of research within the context of higher education institutions in Jordan. This study is valuable for the Instructional Technology leadership because it establishes a cornerstone for any development training program for faculty technology integration at higher education institutions. In addition, this study is beneficial to instructional technologists in understanding faculty reluctance when diffusing new instructions or educational technologies.

As more courses require the use of e-Learning tools, as more funding is required to implement and support these classes, and as more time is required to develop and facilitate these courses, it becomes critical to understand why faculty choose to use or not to use e-Learning tools for their courses support.

\subsection{Purpose of the Study}

The purpose of this study was to identify the degree or level of e-Learning utilization as well as the issues and challenges regarding the use of e-Learning tools in one of higher education institutions in Jordan. Specifically, the study identified the level of e-Learning integration at the UJ, and determined the factors that might be related to faculty use of e-Learning.

\subsection{Significance of the Study}

Conducting research on faculty attitudes toward the use of e-Learning tools in teaching is important because the findings will help understand technology integration. The importance of the obtained information can assist the university in determining the educational costs, and value in terms of e-Learning effectiveness, regarding the technology integration because academic institutions spend millions of dollars per year on technology. In addition, the obtained data can help in determining what academic institutions can do to improve technology integration (such as e-Learning) at their campuses. The obtained data can provide information about what academic institutions can do to reduce, minimize, or overcome the obstacles to technology integration (such as e-Learning) because the level of technology integration has become a source of data upon which to evaluate university performance and reputation (Feeney, 2001).

Identifying faculty attitudes and perceptions toward e-Learning in higher education may lead to a better understanding of the causes of reluctance to e-Learning use. This study helps fill in the gap in the current Educational Technology knowledge base regarding the level of the use of e-Learning in higher education in Jordan and the main challenges associated with successful utilization of e-Learning systems.

\subsection{Questions of the Study}

This study sought to determine the level of e-Learning integration and to identify factors that are related to faculty use of e-Learning at the higher education, in general, and at the University of Jordan, in specific. Consequently, the following research questions were addressed:

- What is the level of integration of e-Learning into teaching and learning at the UJ according to the type of the faculty or discipline (Humanities, Scientific, or Health Faculties); gender; and academic rank?

- What are the factors related to higher education faculty's attitudes toward the use of e-Learning in their classes?

\section{Research Methodology}

This study presents information that will be useful to a number of individuals who have an interest in the diffusion of postsecondary online or Web-based instruction. This includes, but is not limited to, faculty at higher education institutions who are using e-Learning Management Systems and/or potentially will use e-Learning Management Systems, university administrators, and faculty development directors. The results of this study will benefit the expected audience in that it will identify faculty perceptions of what is currently taking place with e-Learning integration at a higher education institution. 
A paper-based survey was sent to all faculty members at the UJ in the beginning of Fall Semester 2012/2013. Data was collected from the participants of the study; then, the survey was analyzed by using the Statistical Package for the Social Sciences (SPSS) statistics software, version 17.0.

\subsection{Population of the Study}

The target population that the researcher would like to generalize about is all faculty members at postsecondary educational institutions in Jordan. However, the accessible population for this study was all faculty members from the University of Jordan drawn from across all academic disciplines, who hold the rank of lecturer, assistant professor, associate professor, or full professor and who were employed full-time at the main campus.

The faculty roster with a complete list of academic faculty members' names, academic rank, and faculties to which they belong to were obtained from the Human Recourses Department (HRD). Based on the information obtained from the HRD database at this university for the academic year 2012-2013, there were 1314 full-time faculty members as identified previously with different ranks. Thus, the accessible population $(N)$ for this study was 1314. Table 1 shows the breakdown of faculty rank per faculty (college) at this public university at the time of this study.

Table 1 . Faculty rank per faculty $(N=1314)$

\begin{tabular}{|c|c|c|c|c|c|}
\hline Faculty & Lecturer & Assistant & Associate & Professor & Total \\
\hline Faculty of Science & 21 & 21 & 33 & 62 & 137 \\
\hline Faculty of Medicine & 19 & 44 & 51 & 35 & 149 \\
\hline Faculty of Nursing & 18 & 16 & 8 & 3 & 45 \\
\hline Faculty of Agriculture & 5 & 13 & 23 & 46 & 87 \\
\hline Faculty of Pharmacy & 18 & 15 & 13 & 16 & 62 \\
\hline Faculty of Dentistry & 3 & 15 & 12 & 15 & 45 \\
\hline Faculty of Engineering and Technology & 18 & 35 & 40 & 41 & 134 \\
\hline Faculty of Rehabilitation Sciences & 16 & 15 & 2 & --- & 33 \\
\hline King Abdullah Second for Information Technology & 17 & 24 & 8 & 9 & 58 \\
\hline Faculty of Foreign Languages & 33 & 17 & 9 & 11 & 70 \\
\hline Faculty of Business & 20 & 19 & 11 & 20 & 70 \\
\hline Faculty of Law & 5 & 11 & 17 & 4 & 37 \\
\hline Faculty of Physical Education & 9 & 7 & 6 & 13 & 35 \\
\hline Faculty of Shari'a (Islamic Studies) & 10 & 20 & 27 & 20 & 77 \\
\hline Faculty of Arts and Design & 23 & 2 & 5 & 1 & 31 \\
\hline Faculty of Educational Sciences & 18 & 18 & 33 & 25 & 94 \\
\hline Faculty of Arts & 14 & 8 & 30 & 36 & 88 \\
\hline Faculty of International Studies and Political Science & 2 & 3 & 5 & 5 & 15 \\
\hline Faculty of Archaeology and Tourism & 5 & 3 & 3 & 3 & 14 \\
\hline Languages Center & 13 & 11 & 9 & --- & 33 \\
\hline Total & 287 & 317 & 345 & 365 & 1314 \\
\hline
\end{tabular}

\subsection{Research Design}

The methodology used in this study, which follows the guidelines recommended by some of the reviewed 
literature (Gammill, 2004; Harrington, Gordon, \& Schibik, 2004; Kim, 2008; Ndahi, 1999; Nelson, 2003), employed quantitative data collection procedures. However, descriptive research was used as a methodology to answer the research questions A non-experimental quantitative research approach was used in this study. The majority of the survey questions took the form of an attitude scale similar to a Likert-type scale. Respondents addressed each statement using a five-point Likert-type response set: $1=$ strongly disagree, $2=$ disagree, $3=$ do not know (neither disagree nor agree), $4=$ agree, $5=$ strongly agree.

\subsection{Data Collection Procedures}

Data were collected in several stages. Stage one involved obtaining institutional approval from the University's Administration. Prior to the survey distribution, an application was submitted to the Office of the Vice President for Scientific Research at this public university and the approval was obtained. Stage two was the survey distribution (both pilot and then primary). After obtaining a list of faculty members' information from HRD, paper-based surveys were sent to the selected full-time faculty members. Faculty members received the distributed surveys describing the intent of the voluntary study and an invitation to participate. All participants were informed of the intent of this study, invited to participate, and ensured confidentiality (Note 2). The instrument was distributed in person and collected by the research assistant.

Stage three was the survey follow-up. Reminder notices were sent to the study participants who did not respond to or had not completed the survey two weeks following the initial distribution. Stage four was an analysis of the survey data. Analysis of completed and returned surveys provided findings of statistically significant issues, patterns, and highlights.

To ensure consistency within collected data, reliability and validity issues were addressed throughout this study. To ensure reliability and validity, the design process of the surveys used in this study included a pilot study $(n=64)$; approximately $5 \%$ of the population $(N=1314)$. After the pilot surveys were reviewed for recommended changes, questions, and consistency, revisions were made to selected questions for the primary survey.

The questions of the survey were designed to determine factors influencing faculty use of e-Learning Web-based tools and perceived factors to not use e-Learning Web-based tools. Respondents were asked to indicate the importance of e-Learning in their particular field of teaching and the likelihood they would use or are using this technology. Potential factors were determined based on previous research and as indicated in the reviewed literature. However, score reliability analyses were conducted for the primary study as detailed in the Results section.

\subsection{Data Analysis Procedures}

Data analysis included the use of frequencies, percentages, means, standard deviations, skewness, kurtosis, Pearson Correlation Coefficient, effect size, and confidence interval. Furthermore, appropriate levels of measurement and different techniques were applied to data measurement, depending on the selected scale measurement. Correlational analysis such as the Pearson Correlation Coefficient ( $r$ ) was used to measure the magnitude and direction of the relationship between selected variables. The correlation test measured the relationship between the dependent variable, which was the level of faculty use or non-use of e-Learning tools, and the independent variables, which were gender, academic rank, motivation factors, and inhibiting factors. Data analysis and computations for all statistical techniques were performed using the SPSS, version 17.0. Then, the results were reported based on the analyzed data.

\section{Results of the Study}

\subsection{The Primary Data Collection}

This public university has 19 faculties and one academic center. The primary survey was distributed on Sunday, September 23, 2012. An initial follow-up reminder notice was sent on Sunday, September 30, 2012; a second follow-up reminder notice was sent on Sunday, October 7, 2012, and the survey was completed by the end of Monday, October 15, 2012. Data obtained from this primary survey was coded and entered into the statistical software program SPSS.

\subsection{Response Rate}

The population for this research study $(N)$ consisted of 1314 full-time faculty members, as shown earlier in Table 1. Sixty-four of these faculty were selected to participate in the pilot test survey $(n=64)$; thus, the accessible population for the primary data collection included 1250 faculty members who were employed full-time during the 2012-2013 fall semester at the UJ $(N=1250)$. Forty-four surveys were undeliverable due to the faculty member mentioned clearly to the research assistant that he/she does not want to participate in the study periods, 
and not to bother him/her in the following-up process. Also, 91 surveys were returned due to one of the following reasons: faculty member on sabbatical leave or the visiting faculty program, faculty member taking a leaving of absence as confirmed by the department secretary, or retired faculty. Thus, only 1115 surveys were delivered.

Three hundred and twenty-one surveys were received out of the 1115; among the 321 surveys there were 53 incomplete surveys, consequently, they were dropped from the study. Two hundred sixty-eight surveys were completed and considered to be the main data for the primary study analysis; thus, the primary study return rate was $24 \%$.

\subsection{Score Reliability Analysis}

A reliability coefficient expresses a relationship between scores of the same individuals on the same instrument at two different times or between two parts of the same instrument. There are several methods that are used to obtain a reliability coefficient. One of these methods is internal consistency via a Cronbach's alpha coefficient $(\alpha)$. Mathematically, Cronbach's score reliability ranges from -1.00 to +1.00 , but in the research literature, it is reported as a range from 0.00 to +1.00 . score reliability with values from 0.81 to 1.00 indicates almost perfect reliability (Landis \& Koch, 1977).

It is important to mention that this study consists of two subgroups: e-Learning faculty users and non-users. In the primary survey, participants of each subgroup were directed to answer some questions based on their classification as e-Learning users or non-users. As a result, two reliability tests were conducted. The first reliability test was run for e-Leaning faculty users concerning the motivation factors only, in which faculty users were asked to rate the extent to which they agree the factors listed in the survey are related to their use of e-Leaning tools. The second reliability test was run for e-Leaning faculty non-users concerning the inhibiting factors only, in which faculty users were asked to rate the extent to which they agree the factors listed in the survey are related to their use of e-Leaning tools.

Table 2 shows the score reliability analysis for e-Learning faculty users $(n=151)$. The Cronbach's alpha value $(\alpha)$ of 0.859 from Table 2 indicates that the items on the primary survey instrument for the subgroup of e-Learning faculty users has substantial score reliability. Also the confidence interval (CI) was calculated and is reported.

Table 2. Reliability statistics for the instrument items for e-learning faculty users $(n=151)$

\begin{tabular}{cccc}
\hline Cronbach's Alpha & $\mathrm{K}$ & \multicolumn{2}{c}{$95 \%$ Confidence Interval } \\
& & Lower Bound & Upper Bound \\
\hline 0.859 & 70 & 0.801 & 0.907 \\
\hline
\end{tabular}

Note: $K=N$ of Items

Table 3 shows the score reliability analysis for e-Learning faculty non-users $(n=117)$. The Cronbach's alpha value of 0.821 from Table 3 indicates that the items on the primary survey instrument for the subgroup of e-Learning faculty non-users has substantial score reliability. Also, the CI was calculated and is reported.

Table 3. Reliability statistics for the instrument items for e-learning faculty non-users $(n=117)$

\begin{tabular}{cccc}
\hline Cronbach's Alpha & $\mathrm{K}$ & \multicolumn{2}{c}{$95 \%$ Confidence Interval } \\
& & Lower Bound & Upper Bound \\
\hline 0.821 & 64 & 0.519 & 0.961 \\
\hline
\end{tabular}

\subsection{The Primary Data Analysis and Findings}

The following is a descriptive analysis of survey research questions. The mean age of respondents is 43 . The respondent group consisted of 178 males (66.4\%) and 90 females (33.6\%). The responding faculty rank consisted of 53 lecturers (19.8\%), 95 assistant professors (35.4\%), 57 associate professors (21.3\%), and 63 full professors $(23.5 \%)$. Table 4 shows the participants' representation with regard to the discipline. 
Table 4. Participants representation with regard to the discipline $(N=268)$

\begin{tabular}{lcc}
\hline Discipline/College & Response Total & Response Percent \\
\hline Faculty of Science & 17 & $6.3 \%$ \\
Faculty of Medicine & 27 & $10.1 \%$ \\
Faculty of Nursing & 9 & $3.4 \%$ \\
Faculty of Agriculture & 13 & $4.9 \%$ \\
Faculty of Pharmacy & 11 & $4.1 \%$ \\
Faculty of Dentistry & 10 & $3.7 \%$ \\
Faculty of Engineering and Technology & 30 & $11.2 \%$ \\
Faculty of Rehabilitation Sciences & 9 & $3.4 \%$ \\
King Abdullah Second for Information Technology & 19 & $7.1 \%$ \\
Faculty of Foreign Languages & 8 & $3.0 \%$ \\
Faculty of Business & 12 & $4.5 \%$ \\
Faculty of Law & 6 & $2.2 \%$ \\
Faculty of Physical Education & 14 & $5.2 \%$ \\
Faculty of Shari'a (Islamic Studies) & 10 & $3.7 \%$ \\
Faculty of Arts and Design & 16 & $6.0 \%$ \\
Faculty of Educational Sciences & 26 & $9.7 \%$ \\
Faculty of Arts & 17 & $6.3 \%$ \\
Faculty of International Studies and Political Science & 4 & $1.5 \%$ \\
Faculty of Archaeology and Tourism & 6 & $2.2 \%$ \\
Languages Center & 4 & $1.5 \%$ \\
Total & 268 & $100 \%$ \\
\hline
\end{tabular}

The type of e-Learning delivery tools faculty members are currently using or previously have used most is Blackboard. Seventy-two faculty members indicated that they are using or have used this type of e-Learning tool (26.8\%). Forty-nine faculty members indicated that they are using or have used JU's Faculty Member Website as an e-Learning delivery tool (18.3\%), and 30 faculty members indicated that they are using or have used Moodle for delivery of their classroom instructions (11.2\%). While 117 faculty members indicated that they have not used any e-Learning tools (43.7\%).

In a question about the level of faculty use of e-Learning tools, 60 faculty members indicated that they have no plans to teach a course using e-Learning tools $(22.4 \%)$. Forty-two faculty members indicated that they plan to teach a course using e-Learning tools, but they are not sure (15.7\%). Fifty-five faculty members indicated that they plan to teach a course using e-Learning tools in the coming year (20.5\%). While 111 faculty members indicated that they either have taught a course using e-Learning tools or currently are teaching a course using e-Learning tools $(41.4 \%)$. The mean number of courses that faculty members have taught utilizing e-Learning tools is four. The mean number of e-Learning training sessions is two.

In a question about the attitudes toward the use of e-Learning tools, seven faculty members indicated they strongly disagree that there is a relationship between exposure to e-Learning tools and attitude toward e-Learning tools $(2.6 \%)$. Fifteen faculty members indicated they disagree that there is a relationship between exposure to e-Learning tools and attitude toward e-Learning tools (5.6\%). Thirty-three faculty members indicated they do not know whether there is a relationship between exposure to e-Learning tools and attitude toward e-Learning tools $(12.3 \%)$. One hundred and fifty-seven faculty members indicated they agree that there is a relationship between exposure to e-Learning tools and attitude toward e-Learning tools (58.6\%). Fifty-six faculty members indicated they strongly agree that there is a relationship between exposure to e-Learning tools and attitude toward e-Learning tools (20.9\%).

Also, in a question about the attitudes toward the use of e-Learning tools, five faculty members indicated they 
strongly disagree that there is a relationship between attitude toward the use of e-Learning and willingness to use e-Learning tools $(1.9 \%)$. Fifteen faculty members indicated they disagree that there is a relationship between attitude toward the use of e-Learning and willingness to use e-Learning tools (5.6\%). Thirty-three faculty members indicated they do not know whether there is a relationship between attitude toward the use of e-Learning and willingness to use e-Learning tools $(12.3 \%)$. One hundred and sixty-one faculty members indicated they agree that there is a relationship between attitude toward the use of e-Learning and willingness to use e-Learning tools $(60.1 \%)$. Fifty-four faculty members indicated they strongly agree that there is a relationship between attitude toward the use of e-Learning and willingness to use e-Learning tools (20.1\%).

In a question asked faculty about their attitudes and support toward the use of e-Learning tools in postsecondary education; only six faculty members indicated that he/she is highly resistant to using e-Learning (2.2\%). Ten faculty members indicated that they resist using e-Learning (3.7\%). Forty faculty members indicated that they have neutral feelings toward the use of e-Learning (14.9\%). One hundred and forty-one faculty members indicated that they support using e-Learning (52.6\%). Seventy-one faculty members indicated that they highly support using e-Learning (26.6\%).

In a question asked about the classification of the e-Learning users, e-Learning faculty users versus e-Learning faculty non-users. One hundred and fifty-one faculty members classified themselves as e-Learning faculty users (56.3\%), whereas 117 faculty members classified themselves as e-Learning faculty non-users $(43.7 \%)$.

In a question was about factors that motivated e-Learning faculty users to use e-Learning tools (this question was for e-Learning faculty users only). Table 5 presents e-Learning faculty users' responses to motivation factors for using e-Learning tools. Faculty who currently are using or previously have used e-Learning tools were asked to rate 1-5 (1-strongly disagree, 2-disagree, 3-neutral, 4-agree, 5-strongly agree) the extent to which they agree the factors listed in the survey are related to their use of e-Learning tools. As mentioned earlier, $56.3 \%$ of respondents reported that they are e-Learning faculty users; $151(n)$ faculty members out of $268(N)$ are e-Learning faculty users. For motivation factor titles, see Appendix A.

Table 5. Survey question 14 results: faculty users' responses to motivation factors for using e-learning $(n=151)$

\begin{tabular}{rrrrrrrrr}
\hline $\begin{array}{l}\text { Factor } \\
\text { Number }\end{array}$ & $\begin{array}{c}\text { Strongly } \\
\text { Disagree }\end{array}$ & Disagree & Neutral & Agree & $\begin{array}{r}\text { Strongly } \\
\text { Agree }\end{array}$ & $\bar{X}$ & Sk & Ku \\
\hline 1 & ---- & $3(2.0 \%)$ & $11(7.3 \%)$ & $82(54.3 \%)$ & $55(36.4 \%)$ & 4.24 & -0.76 & 1.05 \\
2 & $67(44.4 \%)$ & $55(36.4 \%)$ & $18(11.9 \%)$ & $8(5.3 \%)$ & $3(2.0 \%)$ & 1.84 & 1.25 & 1.31 \\
3 & $11(7.3 \%)$ & $21(13.9 \%)$ & $39(25.8 \%)$ & $59(39.1 \%)$ & $21(13.9 \%)$ & 3.38 & -0.52 & -0.39 \\
4 & $53(35.1 \%)$ & $40(26.5 \%)$ & $21(13.9 \%)$ & $27(17.9 \%)$ & $10(6.6 \%)$ & 2.34 & 0.57 & -0.93 \\
5 & $31(20.5 \%)$ & $17(11.3 \%)$ & $26(17.2 \%)$ & $64(42.4 \%)$ & $13(8.6 \%)$ & 3.07 & -0.46 & -1.10 \\
6 & $27(17.9 \%)$ & $23(15.2 \%)$ & $34(22.5 \%)$ & $59(39.1 \%)$ & $8(5.3 \%)$ & 2.99 & -0.41 & -1.04 \\
7 & $23(15.2 \%)$ & $34(22.5 \%)$ & $35(23.2 \%)$ & $53(35.1 \%)$ & $6(4.0 \%)$ & 2.91 & -0.25 & -1.05 \\
8 & $16(10.6 \%)$ & $19(12.6 \%)$ & $19(12.6 \%)$ & $65(43.0 \%)$ & $32(21.2 \%)$ & 3.51 & -0.71 & -0.54 \\
9 & $108(71.5 \%)$ & $24(15.9 \%)$ & $13(8.6 \%)$ & $3(2.0 \%)$ & $3(2.0 \%)$ & 1.48 & 2.13 & 4.49 \\
10 & $48(31.8 \%)$ & $43(28.5 \%)$ & $34(22.5 \%)$ & $21(13.9 \%)$ & $5(3.3 \%)$ & 2.28 & 0.52 & -0.69 \\
11 & $63(41.7 \%)$ & $41(27.2 \%)$ & $24(15.9 \%)$ & $18(11.9 \%)$ & $5(3.3 \%)$ & 2.07 & 0.83 & -0.32 \\
12 & $106(70.2 \%)$ & $23(15.2 \%)$ & $6(4.0 \%)$ & $10(6.6 \%)$ & $6(4.0 \%)$ & 1.60 & 1.92 & 2.65 \\
13 & $58(38.4 \%)$ & $42(27.8 \%)$ & $21(13.9 \%)$ & $21(13.9 \%)$ & $9(6.0 \%)$ & 2.22 & 0.75 & -0.59 \\
14 & $72(47.7 \%)$ & $26(17.2 \%)$ & $14(9.3 \%)$ & $37(24.5 \%)$ & $2(1.3 \%)$ & 2.14 & 0.57 & -1.30 \\
15 & $31(20.5 \%)$ & $22(14.6 \%)$ & $29(19.2 \%)$ & $53(35.1 \%)$ & $16(10.6 \%)$ & 3.01 & -0.27 & -1.18 \\
16 & $92(60.9 \%)$ & $39(25.8 \%)$ & $9(6.0 \%)$ & $8(5.3 \%)$ & $3(2.0 \%)$ & 1.63 & 1.74 & 2.63 \\
17 & $92(60.9 \%)$ & $37(24.5 \%)$ & $9(6.0 \%)$ & $8(5.3 \%)$ & $5(3.3 \%)$ & 1.66 & 1.74 & 2.49 \\
18 & $63(41.7 \%)$ & $27(17.9 \%)$ & $24(15.9 \%)$ & $27(17.9 \%)$ & $10(6.6 \%)$ & 2.30 & 0.55 & -1.06 \\
19 & $21(13.9 \%)$ & $6(4.0 \%)$ & $29(19.2 \%)$ & $72(47.7 \%)$ & $23(15.2 \%)$ & 3.46 & -0.90 & -0.06
\end{tabular}




\begin{tabular}{rrrrrrrrr}
20 & $34(22.5 \%)$ & $14(9.3 \%)$ & $34(22.5 \%)$ & $51(33.8 \%)$ & $18(11.9 \%)$ & 3.03 & -0.32 & -1.14 \\
21 & $2(1.3 \%)$ & $2(1.3 \%)$ & $3(2.0 \%)$ & $79(52.4 \%)$ & $65(43.0 \%)$ & 4.36 & -1.63 & 5.90 \\
22 & $13(8.6 \%)$ & $11(7.3 \%)$ & $29(19.2 \%)$ & $72(47.7 \%)$ & $26(17.2 \%)$ & 3.57 & -0.91 & 0.26 \\
23 & $19(12.6 \%)$ & $8(5.3 \%)$ & $34(22.5 \%)$ & $66(43.7 \%)$ & $24(15.9 \%)$ & 3.45 & -0.81 & -0.14 \\
24 & $29(19.2 \%)$ & $14(9.3 \%)$ & $43(28.5 \%)$ & $55(36.4 \%)$ & $10(6.6 \%)$ & 3.01 & -0.45 & -0.89 \\
25 & $58(38.4 \%)$ & $43(28.5 \%)$ & $35(23.2 \%)$ & $10(6.6 \%)$ & $5(3.3 \%)$ & 2.07 & 0.79 & -0.01 \\
26 & $48(31.8 \%)$ & $42(27.8 \%)$ & $34(22.5 \%)$ & $19(12.6 \%)$ & $8(5.3 \%)$ & 2.32 & 0.57 & -0.63 \\
27 & $39(25.8 \%)$ & $16(10.6 \%)$ & $43(28.5 \%)$ & $40(26.5 \%)$ & $13(8.6 \%)$ & 2.82 & -0.12 & -1.17 \\
28 & $84(55.6 \%)$ & $37(24.5 \%)$ & $19(12.6 \%)$ & $8(5.3 \%)$ & $3(2.0 \%)$ & 1.74 & 1.35 & 1.21 \\
29 & $16(10.6 \%)$ & $10(6.6 \%)$ & $10(6.6 \%)$ & $66(43.7 \%)$ & $49(32.5 \%)$ & 3.82 & -1.16 & 0.34 \\
30 & $8(5.3 \%)$ & $5(3.3 \%)$ & $14(9.3 \%)$ & $68(45.0 \%)$ & $56(37.1 \%)$ & 4.05 & -1.45 & 2.05 \\
31 & $6(4.0 \%)$ & ----- & $39(25.8 \%)$ & $71(47.0 \%)$ & $35(23.2 \%)$ & 3.85 & -1.02 & 1.79 \\
\hline
\end{tabular}

Note: Whole number is row count and number in parenthesis is the percentage

$\chi=$ Mean, $S k=$ Skewness, $K u=$ Kurtosis

In a question was about inhibiting factors that restrained e-Learning faculty non-users from using e-Learning tools (this question was for e-Learning faculty non-users only). Table 6 presents e-Learning faculty non-users' responses to inhibiting factors from using e-Learning tools. Faculty who never have used e-Learning tools were asked to rate 1-5 (1-strongly disagree, 2-disagree, 3-neutral, 4-agree, 5-strongly agree) the extent to which they agree the factors listed in the survey would inhibit them from using e-Learning tools. For inhibiting factor titles, see Appendix B.

Table 6. Survey question 16 results: faculty non-users' responses to inhibiting factors from using e-learning tools $(n=117)$

\begin{tabular}{rrrrrrrrr}
\hline $\begin{array}{l}\text { Factor } \\
\text { Number }\end{array}$ & $\begin{array}{r}\text { Strongly } \\
\text { Disagree }\end{array}$ & Disagree & Neutral & Agree & $\begin{array}{r}\text { Strongly } \\
\text { Agree }\end{array}$ & $\bar{X}$ & Sk & $\mathrm{Ku}$ \\
\hline 1 & $4(3.4 \%)$ & $4(3.4 \%)$ & $17(14.5 \%)$ & $61(52.1 \%)$ & $31(26.6 \%)$ & 3.93 & -1.26 & 2.33 \\
2 & $13(11.1 \%)$ & $31(26.6 \%)$ & $26(22.2 \%)$ & $43(36.7 \%)$ & $4(3.4 \%)$ & 2.96 & -0.27 & -0.98 \\
3 & $4(3.4 \%)$ & $26(22.2 \%)$ & $26(22.2 \%)$ & $48(41.1 \%)$ & $13(11.1 \%)$ & 3.33 & -0.33 & -0.68 \\
4 & $13(11.1 \%)$ & $40(34.3 \%)$ & $30(25.6 \%)$ & $30(25.6 \%)$ & $4(3.4 \%)$ & 2.78 & 0.08 & -0.82 \\
5 & $13(11.1 \%)$ & $44(37.7 \%)$ & $30(25.6 \%)$ & $30(25.6 \%)$ & ----- & 2.67 & 0.00 & -1.08 \\
6 & $9(7.7 \%)$ & $35(29.9 \%)$ & $35(29.9 \%)$ & $29(24.8 \%)$ & $9(7.7 \%)$ & 2.96 & 0.07 & -0.67 \\
7 & $9(7.7 \%)$ & $35(29.9 \%)$ & $48(41.1 \%)$ & $21(17.9 \%)$ & $4(3.4 \%)$ & 2.81 & 0.11 & -0.10 \\
8 & $5(4.4 \%)$ & $21(17.9 \%)$ & $21(17.9 \%)$ & $35(29.9 \%)$ & $35(29.9 \%)$ & 3.63 & -0.46 & -0.87 \\
9 & $26(22.2 \%)$ & $35(29.9 \%)$ & $35(29.9 \%)$ & $13(11.1 \%)$ & $8(6.9 \%)$ & 2.52 & 0.47 & -0.39 \\
10 & $9(7.7 \%)$ & $4(3.4 \%)$ & $21(17.9 \%)$ & $48(41.1 \%)$ & $35(29.9 \%)$ & 3.81 & -1.10 & 0.97 \\
11 & $9(7.7 \%)$ & $44(37.7 \%)$ & $17(14.5 \%)$ & $30(25.6 \%)$ & $17(14.5 \%)$ & 3.04 & 0.17 & -1.20 \\
12 & $9(7.7 \%)$ & $39(33.3 \%)$ & $17(14.5 \%)$ & $39(33.3 \%)$ & $13(11.1 \%)$ & 3.07 & -0.01 & -1.16 \\
13 & $4(3.4 \%)$ & $21(17.9 \%)$ & $30(25.6 \%)$ & $53(45.4 \%)$ & $9(7.7 \%)$ & 3.33 & -0.49 & -0.31 \\
14 & $4(3.4 \%)$ & $17(14.5 \%)$ & $35(29.9 \%)$ & $48(41.1 \%)$ & $13(11.1 \%)$ & 3.41 & -0.45 & -0.11 \\
15 & $13(11.1 \%)$ & $30(25.6 \%)$ & $22(18.9 \%)$ & $35(29.9 \%)$ & $17(14.5 \%)$ & 3.11 & -0.10 & -1.10 \\
16 & $9(7.7 \%)$ & $9(7.7 \%)$ & $22(18.9 \%)$ & $60(51.2 \%)$ & $17(14.5 \%)$ & 3.59 & -1.04 & 0.83 \\
17 & $9(7.7 \%)$ & $9(7.7 \%)$ & $26(22.2 \%)$ & $43(36.8 \%)$ & $30(25.6 \%)$ & 3.67 & -0.81 & 0.15
\end{tabular}




\begin{tabular}{rrrrrrrrr}
\hline 18 & $26(22.2 \%)$ & $17(14.5 \%)$ & $35(29.9 \%)$ & $22(18.9 \%)$ & $17(14.5 \%)$ & 2.89 & 0.02 & -1.08 \\
19 & $13(11.1 \%)$ & $35(29.9 \%)$ & $22(18.9 \%)$ & $30(25.6 \%)$ & $17(14.5 \%)$ & 3.04 & 0.04 & -1.13 \\
20 & $26(22.2 \%)$ & $17(14.5 \%)$ & $39(33.3 \%)$ & $13(11.1 \%)$ & $22(18.9 \%)$ & 2.89 & 0.12 & -1.04 \\
21 & $4(3.4 \%)$ & $9(7.7 \%)$ & $26(22.2 \%)$ & $52(44.5 \%)$ & $26(22.2 \%)$ & 3.74 & -0.83 & 0.68
\end{tabular}

Note: Whole number is row count and number in parenthesis is the percentage.

$\chi=$ Mean, Sk $=$ Skewness, $K u=$ Kurtosis.

\subsubsection{General Findings of Survey Research Questions}

The limits for the skewness and kurtosis that were used in this study were within a range of \pm 2 . Based on this range, skewness and kurtosis of all questions on the survey fall within the indicated range except for motivation factors $9,12,16,17,21$, and 30; and inhibiting factor 1 .

Factor 9 of Question 14 has a skewness of 2.139 and a kurtosis of 4.493. This question asked faculty the extent to which they agree that this factor, increase in salary, is related to their use of e-Learning tools. One hundred and eight faculty members (71.5\%) strongly disagree that increase in salary was a factor for motivating them to use e-Learning tools, which means there was no increase in salary for faculty members by their academic institution to motivate them to use or increase their use of e-Learning tools. Therefore, it can be concluded that an increase in salary is an important factor for faculty use of e-Learning tools.

Factor 12 of Question 14 has a kurtosis of 2.652. This question asked faculty the extent to which they agree that this factor, receiving a stipend for using e-Learning, is related to their use of e-Learning tools. One hundred and six faculty members (70.2\%) strongly disagree that receiving a stipend for using e-Learning was a factor to motivate them to use e-Learning tools, which means there was no stipend for using e-Learning provided by this institution to its faculty to motivate them to use or increase their use of e-Learning tools. Therefore, it can be concluded that receiving a stipend for using e-Learning is an important factor for faculty use of e-Learning tools.

Factor 16 of Question 14 has a kurtosis of 2.639. This question asked faculty the extent to which they agree that this factor, release time, is related to their use of e-Learning tools. Ninty-two faculty members $(60.9 \%)$ strongly disagree that release time was a factor to motivate them to use e-Learning tools (it could be due to overload teaching hours), which means faculty have limited free time to motivate them to use or increase their use of e-Learning tools. Therefore, it can be concluded that release time is an important factor for faculty use of e-Learning tools.

Factor 17 of Question 14 has a kurtosis of 2.496. This question asked faculty the extent to which they agree that this factor, merit pay, is related to their use of e-Learning tools. Merit pay means higher salaries for higher professional achievement, including the use of e-Learning. Ninty-two faculty members $(60.9 \%)$ strongly disagree that merit pay was a factor to motivate them to use e-Learning tools. Therefore, it can be concluded that merit pay is an important factor for faculty that related to their use of e-Learning tools.

Factor 21 of Question 14 has a kurtosis of 5.904. This question asked faculty the extent to which they agree that this factor, greater course flexibility for students, is related to their use of e-Learning tools. Greater course flexibility for students means a higher degree of flexibility for students in terms of class communication and turning in assignments. Seventy-nine faculty members (52.4\%) agree and 65 faculty members (43.0\%) strongly agree that greater course flexibility for students was a motivating factor to their use of e-Learning tools. Therefore, it can be concluded that greater course flexibility for students is an important factor for faculty use of e-Learning tools. In other words, faculty were motivated or would be motivated to use e-Learning tools because they believe that e-Learning tools provide a greater course flexibility for their students.

Factor 30 of Question 14 has a kurtosis of 2.053. This question asked faculty the extent to which they agree that this factor, opportunity to improve teaching, is related to their use of e-Learning tools. Opportunity to improve teaching means making teaching and learning more effective, providing effective instruction, and improving teaching and learning outcomes. Sixty-eight faculty members (45.0\%) agree and 56 faculty members (37.1\%) strongly agree that the opportunity to improve teaching was a motivating factor to their use of e-Learning tools. Therefore, it can be concluded that the opportunity to improve teaching is an important factor for faculty use of e-Learning tools. In other words, faculty members were motivated or would be motivated to use e-Learning tools because they believe that e-Learning tools provide an opportunity to improve their teaching. 
Factor 1 of Question 16 has a kurtosis of 2.338. This question asked faculty the extent to which they agree that this factor, faculty workload, is related to their use of e-Learning tools. Sixty-one faculty members $(52.1 \%)$ agree and 31 faculty members $(26.6 \%)$ strongly agree that the teaching workload was an inhibiting factor to their use of e-Learning tools. Therefore, it can be concluded that the teaching workload is an important factor for faculty use of e-Learning tools.

Data from the completed surveys reveal that males participated (66.4\%) more than females (33.6\%); assistant professors (35.4\%) were the majority among the participants in terms of faculty rank. The Faculty of Engineering and Technology (11.2\%) was the majority among the faculties in this public university in terms of discipline. Blackboard (26.8\%) was the most dominant e-Learning tool used at this public university. Faculty members who either have taught a course using e-Learning tools or currently are teaching a course using e-Learning tools $(41.4 \%)$ were the majority among the participants. The majority of the participants (79.5\%) either agree or strongly agree that there is a relationship between exposure to e-Learning tools and attitude toward e-Learning tools. The majority of the participants $(80.1 \%)$ either agree or strongly agree that there is a relationship between attitude toward the use of e-Learning and willingness to use e-Learning tools. The attitude of the majority of the participants toward the use of e-Learning (79.1\%) is either supportive or highly supportive. The number of e-Learning user participants (56.3\%) was greater than e-Learning non-user participants (43.7\%).

\subsubsection{General Findings Regarding E-Learning Faculty Users}

Data from the completed surveys reveal that the majority of the e-Learning user participants either agree or strongly agree that the following motivating factors were related most commonly to their use of e-Learning tools: personal motivation to use e-Learning, adequate training received, encouragement from institution administrators, more flexible working conditions, overall job satisfaction, greater course flexibility for students, e-Learning training provided by the institution, time convenience, opportunity to improve teaching, and characteristics of e-Learning.

The results from the completed surveys also reveal that the majority of the e-Learning user participants either disagree or strongly disagree that the following motivating factors were related to their use of e-Learning tools: reduce teaching loads, increase in salary, strengthened job security, receive a stipend for using e-Learning, credit toward promotion and tenure, release time, merit pay, professional prestige and status, and recognition/rewards from the administration.

\subsubsection{General Findings Regarding e-Learning Faculty Non-Users}

Completed surveys indicate that the majority of the e-Learning non-user participants either agree or strongly agree that the following inhibiting factors were related to their decision about whether to make use of e-Learning tools: faculty workload, e-Learning training provided by the institution, negative comments made by colleagues about e-Learning, release time, technological background, technical support provided by the institution, monetary support, concern about students' technological skills, concern about loss of control over teaching process, and change in faculty role.

The survey results also reveal that the majority of the e-Leaning non-user participants either disagree or strongly disagree that the following inhibiting factors were related to their use of e-Leaning tools: encouragement from departmental colleagues, support from dean or department chair, administrative support, administrative encouragement, professional prestige, merit pay, recognition/rewards, salary implications, and credit toward promotion and tenure.

Furthermore, data from the completed surveys reveal that the majority of the e-Learning non-user participants would be (a) interested in using e-Learning in the future, (b) willing to or interested in teaching a course that utilizes e-Learning tools in the future, and (c) interested in receiving training about the use of e-Learning in the future. E-Learning non-user participants indicated that the most major deterrents to their teaching a course that utilizes e-Learning tools in the future are they not interested in using e-Learning and do not believe that e-Learning would be an effective teaching method for their field of teaching. Tables 7, 8, and 9 illustarte the distribution of the participants of the study (e-Learning faculty users and non-users) acoording to faculty users and non-users' gender, faculty users's rank, and faculty non-users' rank, respectively. 
Table 7. Faculty paricipants users and non-users according to gender $(N=268)$

\begin{tabular}{|c|c|c|c|c|c|}
\hline \multirow[b]{2}{*}{ Faculty } & \multicolumn{2}{|c|}{ Users } & \multicolumn{2}{|c|}{ Non-User } & \multirow[b]{2}{*}{ Total } \\
\hline & Male & Female & Male & Female & \\
\hline Faculty of Science & 4 & 5 & 6 & 2 & 17 \\
\hline Faculty of Medicine & 11 & 1 & 15 & --- & 27 \\
\hline Faculty of Nursing & 1 & 4 & 1 & 3 & 9 \\
\hline Faculty of Agriculture & 5 & 2 & 4 & 2 & 13 \\
\hline Faculty of Pharmacy & 2 & 4 & 4 & 1 & 11 \\
\hline Faculty of Dentistry & 3 & 2 & 4 & 1 & 10 \\
\hline Faculty of Engineering and Technology & 17 & 1 & 9 & 3 & 30 \\
\hline Faculty of Rehabilitation Sciences & 1 & 4 & --- & 4 & 9 \\
\hline King Abdullah Second for Information Technology & 8 & 11 & --- & --- & 19 \\
\hline Faculty of Foreign Languages & 1 & 3 & 3 & 1 & 8 \\
\hline Faculty of Business & 8 & 1 & 2 & 1 & 12 \\
\hline Faculty of Law & 2 & 2 & 2 & --- & 6 \\
\hline Faculty of Physical Education & 5 & 1 & 7 & 1 & 14 \\
\hline Faculty of Shari'a (Islamic Studies) & 2 & 1 & 5 & 2 & 10 \\
\hline Faculty of Arts and Design & 7 & 3 & 4 & 2 & 16 \\
\hline Faculty of Educational Sciences & 7 & 7 & 9 & 3 & 26 \\
\hline Faculty of Arts & 4 & 3 & 8 & 2 & 17 \\
\hline Faculty of International Studies and Political Science & 2 & 1 & 1 & --- & 4 \\
\hline Faculty of Archaeology and Tourism & 1 & 2 & 3 & --- & 6 \\
\hline Languages Center & --- & 2 & --- & 2 & 4 \\
\hline Total & 91 & 60 & 87 & 30 & 268 \\
\hline
\end{tabular}

Table 8 . Faculty users paricipants according to faculty rank $(n=151)$

\begin{tabular}{lccccc}
\hline Faculty & Lecturer & Assistant & Associate & Professor & Total \\
\hline Faculty of Science & 1 & 3 & 3 & 2 & 9 \\
Faculty of Medicine & --- & 6 & 3 & 3 & 12 \\
Faculty of Nursing & --- & 3 & 2 & --- & 5 \\
Faculty of Agriculture & 1 & 4 & 1 & 1 & 7 \\
Faculty of Pharmacy & --- & 3 & 1 & 2 & 6 \\
Faculty of Dentistry & --- & 2 & 3 & --- & 5 \\
Faculty of Engineering and Technology & 1 & 6 & 7 & 4 & 18 \\
Faculty of Rehabilitation Sciences & --- & 5 & --- & --- & 5 \\
King Abdullah Second for Information Technology & 1 & 15 & 3 & --- & 19 \\
Faculty of Foreign Languages & --- & 3 & --- & 1 & 4
\end{tabular}


Faculty of Business

Faculty of Law

Faculty of Physical Education

Faculty of Shari'a (Islamic Studies)

Faculty of Arts and Design

Faculty of Educational Sciences

Faculty of Arts

Faculty of International Studies and Political Science

Faculty of Archaeology and Tourism

Languages Center

Total

$\begin{array}{rrrrr}-- & 4 & 3 & 2 & 9 \\ --- & 2 & 2 & --- & 4 \\ --- & 3 & 2 & 1 & 6 \\ --- & 2 & 1 & --- & 3 \\ 3 & 3 & 1 & 3 & 10 \\ 1 & 7 & 3 & 3 & 14 \\ 1 & 3 & --- & 3 & 7 \\ 1 & 1 & --- & 1 & 3 \\ --- & 1 & 2 & --- & 3 \\ --- & --- & 2 & --- & 2 \\ \mathbf{1 0} & \mathbf{7 6} & \mathbf{3 9} & \mathbf{2 6} & \mathbf{1 5 1}\end{array}$

Table 9. Faculty non-users paricipants according to faculty rank $(n=117)$

\begin{tabular}{|c|c|c|c|c|c|}
\hline Faculty & Lecturer & Assistant & Associate & Professor & Total \\
\hline Faculty of Science & --- & 2 & 2 & 4 & 8 \\
\hline Faculty of Medicine & --- & 8 & 5 & 2 & 15 \\
\hline Faculty of Nursing & --- & 4 & --- & --- & 4 \\
\hline Faculty of Agriculture & 1 & 2 & 1 & 2 & 6 \\
\hline Faculty of Pharmacy & 1 & 2 & 1 & 1 & 5 \\
\hline Faculty of Dentistry & --- & --- & 3 & 2 & 5 \\
\hline Faculty of Engineering and Technology & 3 & 2 & 1 & 6 & 12 \\
\hline Faculty of Rehabilitation Sciences & 1 & 3 & --- & --- & 4 \\
\hline King Abdullah Second for Information Technology & --- & --- & --- & --- & --- \\
\hline Faculty of Foreign Languages & --- & 4 & --- & --- & 4 \\
\hline Faculty of Business & --- & 3 & --- & --- & 3 \\
\hline Faculty of Law & --- & --- & 1 & 1 & 2 \\
\hline Faculty of Physical Education & --- & 3 & 3 & 2 & 8 \\
\hline Faculty of Shari'a (Islamic Studies) & 1 & 3 & 1 & 2 & 7 \\
\hline Faculty of Arts and Design & 1 & 3 & 1 & 1 & 6 \\
\hline Faculty of Educational Sciences & --- & 3 & 4 & 5 & 12 \\
\hline Faculty of Arts & --- & 2 & 6 & 2 & 10 \\
\hline Faculty of International Studies and Political Science & --- & --- & --- & 1 & 1 \\
\hline Faculty of Archaeology and Tourism & --- & 2 & --- & 1 & 3 \\
\hline Languages Center & --- & 1 & --- & 1 & 2 \\
\hline Total & 8 & 47 & 29 & 33 & 117 \\
\hline
\end{tabular}




\section{Discussion}

The level of e-Learning integration at the UJ, in the context of gender, faculty rank, and discipline; along with the factors related to higher education faculty's attitudes toward the use of e-Learning tools in their classes were examined, evaluated, and identified in this study; in addition, a number of results were obtained from the data analysis of the study. The study findings on the first research question reveal that there is no relationship between gender and the level of faculty use of e-Learning tools. The Pearson correlation coefficient $(r)$ for this relationship is 0.113 ; the correlation has a probability $(p)$ value of 0.212 for 2-tailed test. A weak positive correlation that was not statistically significant was found $(r(119)=0.113, p>.05,2$-tailed). Therefore, faculty gender is not related to the level of faculty use of e-Learning tools. This result is consistent with what was found in Kim's (2008) study.

The study findings on the first research question also reveal that there is a relationship between faculty rank and the level of faculty use of e-Learning, for alpha ( $\alpha$ ) level of .05. According to Kim (2008) and Morgan (2003), full professors, associate professors, and assistant professors are using e-Learning tools at the same level. Table 10 presents a correlation matrix for the indicated relationship. The Pearson correlation coefficient $(r)$ is -0.251 ; the correlation has a probability $(p)$ value of 0.006 for 2-tailed test. A weak negative correlation (as the faculty rank increases, the level of faculty use of e-Learning decreases) that was statistically significant was found $(r(119)=-0.251, p<.05,2$-tailed). Higher faculty rank subjects tend to use e-Learning tools less. Therefore, faculty rank is related to the level of faculty use of e-Learning tools. This result is inconsistent with what was found in Kim's (2008) and Morgan's (2003) studies. However, because this result was found to be statistically significant, it is important to report the coefficient of determination value $\left(r^{2}\right)$ as an effect size (ES).

Table 10. Correlation for faculty rank and the level of faculty use of e-learning $(N=268)$

\begin{tabular}{llr}
\hline Variable Name & & Faculty e-Learning Use \\
\hline Faculty Rank & Pearson Correlation & $-0.251^{*}$ \\
& $95 \%$ CI & $(-0.411,-0.076)$ \\
& Sig. (2-tailed) & 0.006 \\
& Power & 0.80 \\
& $\mathrm{~N}$ & 268 \\
\hline
\end{tabular}

$*=$ Correlation is significant at the 0.05 level.

The $r$ for this result is .251 , thus, $r^{2}=.063$, which represents a small effect size. This coefficient of determination value indicates that about $6 \%$ of the variance in the level of faculty use of e-Learning is accounted for by the presence of variable faculty rank. However, the confidence interval (CI) was also calculated and reported in Table 10.

Overall, faculty participants (users and non-users) indicated that lack of institutional incentives is an obstacle to using e-Learning tools, e-Learning is difficult to utilize without the proper training, and adequate institutional support are major concerns in utilizing e-Learning tools. Particularly, an increase in salary, receiving a stipend for using e-Learning, receiving a recognition or reward from the administration, merit pay, release time, teaching workload, and training in the use of e-Learning were the most important factors related to faculty use of e-Learning tools at this public university. E-Learning tools are currently integrated into instruction at this public university to an acceptable level of use. Data from the completed surveys reveal that the majority of the participants $(56.3 \%)$ indicated that their departments or faculties are currently utilizing e-Learning.

Data from the completed surveys reveal that lack of incentives for using e-Learning in instruction was a major concern or issue related to the level of faculty use of e-Learning tools in this study. This finding was confirmed by the literature; the findings of Anderson's (2003), Butler and Sellbom's (2002), Kim's (2008), Morgan's (2003), Muilenburg and Berge's (2001), and Ndahi's (1999) studies imply clearly that institutional incentives, support, and encouragement are essential factors for successful implementation of new technology in higher education settings

\section{Conclusion and Recommendations}

This study identified prevalent faculty perceptions toward the use of e-Learning tools in higher education at one 
public Jordanian university, explored the level of integration of e-Learning at the UJ, and examined the factors that are related to faculty's attitudes toward the use of e-Learning tools, and probed what one academic institution can do to improve the utilization of e-Learning at its campus. Specifically, this research examined the association between the level of faculty use of e-Learning and faculty gender, faculty rank, motivation factors, and inhibiting factors.

The study put forward the following recommendations to improve the utilization of e-Learning at the institutions of higher education in Jordan, in general, and particularly at the UJ: (1) offer more training sessions in the use of e-Learning tools; (2) offer workshops concerning the technical issues in using e-Learning tools; (3) reduce teaching loads to make more time available for employing e-Learning tools; (4) offer rewards and incentives for using e-Learning tools; and (4) offer adequate encouragement and support concerning the use of e-Learning tools such as establishing or activating faculty development programs that focus on the use of e-Learning tools.

\section{References}

Afshari, M., Bakar, K., Luan, W., Samah, B., \& Fooi, F. (2009). Factors affecting teachers' use of information and communication technology. International Journal of Instruction, 2(1), 77-104.

Al-Adwan, A., \& Smedley, J. (2012). Implementing e-learning in the Jordanian Higher Education System: Factors affecting impact. International Journal of Education and Development using ICT, 8(1), 121-135.

Al-Shboul, M. (2007). Faculty attitudes and perceptions concerning the use of course management systems in higher education. Unpublished Dissertation, Northern Illinois University, DeKalb, IL.

Al-Shboul, M. (2010). Challenges of Utilizing E-Learning Systems in Public Universities in Jordan. International Journal of Emerging Technologies in Learning, 5(2), 4-10.

Al-Shboul, M. (2011). Potential use of course management systems in higher education institutions in Jordan. US-China Education Review, 8(2), 220-232.

Anderson, J. (2003). Faculty perspectives of the Blackboard course delivery system. Paper presented at the Annual Meeting of the Mid-South Educational Research Association (Biloxi, MS, November 5-7, 2003).

Babić, S. (2012). Factors that influence academic teacher's acceptance of e-learning technology in blended learning environment. In E. Pontes, A. Silva, A. Guelfi, \& S. Takeo-Kofuji (Eds.), E-Learning-Organizational Infrastructure and Tools for Specific Areas (pp. 3-18). Rijeka, Croatia: InTech.

Butler, D., \& Sellbom, M. (2002). Barriers to adopting technology for teaching and learning. Educause Quarterly, 25(2), 22-28.

Chapman, D., \& Mahlk, L. (2004). Adapting technology for school improvement: A global perspective. International Institute for Educational Planning. Retrieved from http://www.unesco.org/iiep/PDF/pubs/F165.pdf

Chin, K., \& Kon, P. (2004). Critical Success Factors for E-Learning. In Proceedings of the IADIS International Conference e-Society (pp. 235-242).

Chism, N. (2004). Using a framework to engage faculty in instructional technologies. Educause Quarterly, 27(2), $39-45$.

Cho, S., \& Berge, Z. (2002). Overcoming barriers to distance training and education. USDLA Journal, 16(1), 16-34.

Christensen, R. (2002). Effects of technology integration education on the attitudes of teachers and students. Journal of Research on Technology in Education, 34(4), 411-433.

Clifford, J., Earp, S., \& Reisinger, D. (2003). Course management systems and foreign language curricula: The case of Blackboard at Duke University. In R. Terry, L. Lomicka, \& J. Cooke-Plagwitz (Eds.), The Heinle professional series in language instruction (Vol. 1, pp. 2-8). Toronto, Canada: Thomson-Heinle.

Coogan, T. (2009). Exploring the hybrid course design for adult learners at the graduate level. Journal of Online Learning and Teaching, 5(2), 316-324.

Crawford, G., \& Rudy, J. (2003). Fourth annual Educause survey identifies current IT issues. Educause Quarterly, 26(2), 12-26.

Cuban, L. (2001). Oversold and underused: Computers in the classroom. Cambridge, MA: Harvard University Press. 
Dietz-Uhler, B., \& Bishop-Clark, C. (2001). The use of computer-mediated communication to enhance subsequent face-to-face discussions. Computers in Human Behavior, 17(3), 269-283. http://dx.doi.org/10.1016/S0747-5632(01)00006-1

Ely, D. (2002). Trends in educational technology. (5th ed.). Syracuse, NY: ERIC Clearinghouse on Information and Technology. (ED 477 511)

Feeney, D. (2001). Rates of adoption in a university course management system. Unpublished Dissertation, West Virginia University, Morgantown, WV.

Gammill, T. (2004). Factors associated with faculty use of web-based instruction in higher education. Unpublished Dissertation, Mississippi State University, Starkville, MS.

Gautreau, C. (2011). Motivational Factors Affecting the Integration of a Learning Management System by Faculty. Journal of Educators Online, 8(1), 1-25. Retrieved from http://www.thejeo.com/Archives/Volume8Number1/GautreauPaper.pdf

Grandgenett, D. (2001). Problem resolution through electronic mail: A five-step model. Innovations in Education \& Teaching International, 38(4), 347-353. http://dx.doi.org/10.1080/14703290110074560

Green, K. (2002). The 2002 national survey of information technology in US higher education: Campus portals make progress; technology budgets suffer significant cuts. Retrieved October 13, 2012, from http://www.campuscomputing.net/

Hannafin, R. (1999). Can teacher attitudes about learning be changed? Journal of Computing in Higher Education, 15(2), 7-13.

Harrington, C., Gordon, S., \& Schibik, T. (2004). Course management system utilization and implications for practice: A national survey of department chairpersons. Online Journal of Distance Learning Administration, 7(4), 1-13.

Irani, T., \& Telg, R. (2007). Building it so they will come: Assessing universities' distance education faculty training and development programs. The Journal of Distance Education, 17(1), 36-46.

Jamlan, M. (2004). Faculty opinions towards introducing e-Learning at the University of Bahrain. The International Review of Research in Open and Distance Learning, 5(2), 1-14.

Kagima, L. (2001). Faculty: The central element in instructional technology integration. Journal of Family and Consumer Sciences, 93(4), 33-36.

Kim, M. (2008). Factors influencing the acceptance of e-learning courses for mainstream faculty in higher institutions. International Journal of Instructional Technology and Distance Learning, 5(2), 29-44.

Landis, J. R., \& Koch, G. G. (1977). The measurement of observer agreement for categorical data. Biometrics, 33, 159-174. http://dx.doi.org/10.2307/2529310

Lynch, D. (2002). Professors should embrace technology in courses. Chronicle of Higher Education, 48(19), B15. Retrieved from http://chronicle.com/article/Professors-Should-Embrace/34437/

Macpherson, A., Homan, G., \& Wilkinson, K. (2005). The implementation and use of e-learning in the corporate university. Journal of Workplace Learning, 17(1), 33-48. http://dx.doi.org/10.1108/13665620510574441

Molenda, M., \& Sullivan, M. (2003). Issues and trends in instructional technology: Treading water. In M. A. Fitzgerald, M. Orey, \& R. M. Branch (Eds.), Educational media and technology yearbook 2003 (Vol. 28, pp. 3-20). Westport, CT: Libraries Unlimited.

Morgan, G. (2003). Faculty use of course management systems. Educause Center for Applied Research. Retrieved October 22, 2012, from http://net.educause.edu/ir/library/pdf/ERS0302/ekf0302.pdf

Muilenburg, L., \& Berge, Z. (2001). Barriers to distance education: A factor-analytic study. The American Journal of Distance Education, 15(2), 7-22. http://dx.doi.org/10.1080/08923640109527081

Ndahi, H. (1999). Utilization of distance learning technology among industrial and technical teacher education faculty. Journal of Industrial Teacher Education, 36(4), 21-37.

Nelson, J. (2003). Integration of course management system communication tools in instruction. Unpublished Dissertation, University of Tennessee, Knoxville, TN.

Ong, C., Lai, J., \& Wang, Y. (2004). Factors affecting engineers' acceptance of asynchronous e-learning systems in high-tech companies. Information \& management, 41(6), 795-804. 
http://dx.doi.org/10.1016/j.im.2003.08.012

Oravec, J. (2003) Some influences of online distance learning on US higher education. Journal of Further and Higher Education, 27(1), 89-104. http://dx.doi.org/10.1080/03098770305628

Reilly, J., Vandenhouten, C., Gallagher-Lepak, S., \& Ralston-Berg, P. (2012). Faculty Development for E-Learning: A Multi-Campus Community of Practice (COP) Approach. Journal of Asynchronous Learning Networks, 16(2), 99-110.

Reiser, R., \& Dempsey, J. (2002). Trends and issues in instructional design and technology. Upper Saddle River, NY: Merril Prentice Hall.

Roca, J., Chiu, C., \& Martínez, F. (2006). Understanding e-learning continuance intention: An extension of the Technology Acceptance Model. International Journal of Human-Computer Studies, 64(8), 683-696. http://dx.doi.org/10.1016/j.ijhcs.2006.01.003

Rogers, P. (2000). Barriers to adopting emerging teachnologies in education. Journal of Computing Research, 22(4), 455-472. http://dx.doi.org/10.2190/4UJE-B6VW-A30N-MCE5

Seels, B., \& Richey, R. (1994). Instructional technology: The definition and domains of the field. Bloomington, IN: Association for Educational Communications and Technology.

Selim, H. (2007). Critical success factors for e-learning acceptance: Confirmatory factor models. Computers \& Education, 49, 396-413. http://dx.doi.org/10.1016/j.compedu.2005.09.004

Strudler, A., \& Wetzel, N. (1999). Lessons from exemplary colleges of education: Factors affecting technology integration in preservice programs. Educational Technology Research and Development, 47(4), 63-81. http://dx.doi.org/10.1007/BF02299598

Tolmie, A., \& Boyle, J. (2000). Factors influencing the success of computer mediated communication (CMC) environments in university teaching: A review and case study. Computers \& Education, 34(2), 119-140. http://dx.doi.org/10.1016/S0360-1315(00)00008-7

Walsh, S. (1993). Attitudes and perceptions of university faculty toward technology based distance education. Unpublished Dissertation, University of Oklahoma, Norman, OK.

Warner, D. (2003). Student recommendations for discussions board: Conclusions of student problems. Paper presented at the Annual Conference of the Mid-South Instructional Technology. Murfreesboro, TN, March 30-April 1, 2003.

Wilson, W. (2003). Faculty perceptions and uses of instructional technology. Educause Quarterly, 26(2), 60-62.

\section{Appendix A}

\section{Motivating Factors}

For faculty who currently are using or previously have used e-Learning tools, rate 1-5 (1-strongly disagree to 5 -strongly agree) the extent to which you agree the factors listed below are related to your use of e-Learning tools.

\begin{tabular}{lccccc}
\hline & Strongly & & \multicolumn{2}{c}{ Strongly } \\
Motivation factors to use of e-Learning & Disagree & Disagree & Neutral & Agree & Agree \\
\hline Personal motivation to use e-Learning & 1 & 2 & 3 & 4 & 5 \\
Reduced teaching loads & 1 & 2 & 3 & 4 & 5 \\
Adequate training received & 1 & 2 & 3 & 4 & 5 \\
Required by department & 1 & 2 & 3 & 4 & 5 \\
Support from dean or department chair & 1 & 2 & 3 & 4 & 5 \\
Support from institution administrators & 1 & 2 & 3 & 4 & 5 \\
Encouragement from institution administrators & 1 & 2 & 3 & 4 & 5 \\
More flexible working conditions & 1 & 2 & 3 & 4 & 5 \\
Increase in salary & 1 & 2 & 3 & 4 & 5 \\
Opportunity to influence social change & 1 & 2 & 3 & 4 & 5 \\
Strengthened job security & 1 & 2 & 3 & 4 & 5 \\
Receiving a stipend for using e-Learning & 1 & 2 & 3 & 4 & 5 \\
Administrative pressure to use e-Learning & 1 & 2 & 3 & 4 & 5 \\
Credit toward promotion and tenure & 1 & 2 & 3 & 4 & 5 \\
Encouragement from departmental colleagues & 1 & 2 & 3 & 4 & 5
\end{tabular}


Release time

Merit pay

Professional prestige and status

Overall job satisfaction

Course assignment

Greater course flexibility for students

Technical support provided by the institution

e-Learning training provided by the institution

Provision of e-Learning training by administration

Royalties on copyrighted materials

Protection of intellectual property rights

Opportunity to teach experience diversity

Recognition/rewards from the administration

Time convenience

Opportunity to improve teaching

Characteristics of e-Learning

$\begin{array}{lllll}1 & 2 & 3 & 4 & 5 \\ 1 & 2 & 3 & 4 & 5 \\ 1 & 2 & 3 & 4 & 5 \\ 1 & 2 & 3 & 4 & 5 \\ 1 & 2 & 3 & 4 & 5 \\ 1 & 2 & 3 & 4 & 5 \\ 1 & 2 & 3 & 4 & 5 \\ 1 & 2 & 3 & 4 & 5 \\ 1 & 2 & 3 & 4 & 5 \\ 1 & 2 & 3 & 4 & 5 \\ 1 & 2 & 3 & 4 & 5 \\ 1 & 2 & 3 & 4 & 5 \\ 1 & 2 & 3 & 4 & 5 \\ 1 & 2 & 3 & 4 & 5 \\ 1 & 2 & 3 & 4 & 5 \\ 1 & 2 & 3 & 4 & 5\end{array}$

\section{Appendix B}

\section{Inhibiting Factors}

For faculty who never have used e-Learning tools, rate 1-5 (1-strongly disagree to 5-strongly agree) the extent to which you agree the factors listed below would inhibit you (or influence your decision) to use e-Learning tools.

\begin{tabular}{lccccc}
\hline & Strongly & & \multicolumn{2}{c}{ Strongly } \\
Inhibiting factors from using e-Learning & Disagree & Disagree & Neutral & Agree & Agree \\
\hline Faculty workload & 1 & 2 & 3 & 4 & 5 \\
e-Learning training provided by the institution & 1 & 2 & 3 & 4 & 5 \\
Negative comments about e-Learning & 1 & 2 & 3 & 4 & 5 \\
Encouragement from departmental colleagues & 1 & 2 & 3 & 4 & 5 \\
Support from dean or department chair & 1 & 2 & 3 & 4 & 5 \\
Administrative support & 1 & 2 & 3 & 4 & 5 \\
Administrative encouragement & 1 & 2 & 3 & 4 & 5 \\
Release time & 1 & 2 & 3 & 4 & 5 \\
Professional prestige & 1 & 2 & 3 & 4 & 5 \\
Technological background & 1 & 2 & 3 & 4 & 5 \\
Merit pay & 1 & 2 & 3 & 4 & 5 \\
Technical support provided by the institution & 1 & 2 & 3 & 4 & 5 \\
Royalties on copyrighted materials & 1 & 2 & 3 & 4 & 5 \\
Protection of intellectual property rights & 1 & 2 & 3 & 4 & 5 \\
Monetary support (e.g., stipend, overload) & 1 & 2 & 3 & 4 & 5 \\
Concern about students' technological skills & 1 & 2 & 3 & 4 & 5 \\
Concern about loss of control over teaching process & 1 & 2 & 3 & 4 & 5 \\
Recognition or rewards & 1 & 2 & 3 & 4 & 5 \\
Salary implication & 1 & 2 & 3 & 4 & 5 \\
Credit toward promotion and tenure & 1 & 2 & 3 & 4 & 5 \\
Change in faculty role & 1 & 2 & 3 & 4 & 5 \\
\hline
\end{tabular}

